\title{
Latitude of the study place and age of the patient are associated with incidence of mediastinitis and microbiology in open-heart surgery: a systematic review and meta-analysis
}

\author{
This article was published in the following Dove Press journal: \\ Clinical Epidemiology \\ 2 June 2016 \\ Number of times this article has been viewed
}

\section{Abdelnoor ${ }^{1,2}$ \\ $\varnothing$ A Vengen ${ }^{3}$ \\ O Johansen ${ }^{4}$ \\ I Sandven ${ }^{2}$ \\ AM Abdelnoor ${ }^{5}$}

'Centre for Clinical Heart Research, Department of Cardiology ${ }^{2}$ Oslo

Centre for Biostatistics and Epidemiology, ${ }^{3}$ Department of

Cardiovascular Surgery, ${ }^{4}$ Department of Cardiology, Oslo University Hospital, Oslo, Norway; ${ }^{5}$ Department of Experimental Pathology, Immunology and Microbiology, American University of Beirut, Beirut, Lebanon
Correspondence: MAbdelnoor Centre for Clinical Heart Research, Oslo University Hospital, Ullevaal, Kirkeveien 166, 02770 Oslo, Norway Tel +47995 40888

Email michelab@online.no
Objective: We aimed to summarize the pooled frequency of mediastinitis following open-heart surgery caused by Gram-positive bacteria, including methicillin-resistant Staphylococcus aureus (MRSA), and Gram-negative bacteria.

Design: This study was a systematic review and a meta-analysis of prospective and retrospective cohort studies.

Materials and methods: We searched the literature, and a total of 97 cohort studies were identified. Random-effect model was used to synthesize the results. Heterogeneity between studies was examined by subgroup and meta-regression analyses, considering study and patientlevel variables. Small-study effect was evaluated.

Results: Substantial heterogeneity was present. The estimated incidence of mediastinitis evaluated from 97 studies was $1.58 \%$ (95\% confidence intervals [CI] 1.42, 1.75) and that of Grampositive bacteria, Gram-negative bacteria, and MRSA bacteria evaluated from 63 studies was $0.90 \%$ (95\% CI 0.81, 1.21), 0.24\% (95\% CI 0.18, 0.32), and 0.08\% (95\% CI 0.05, 0.12), respectively. A meta-regression pinpointed negative association between the frequency of mediastinitis and latitude of study place and positive association between the frequency of mediastinitis and the age of the patient at operation. Multivariate meta-regression showed that prospective cohort design and age of the patients and latitude of study place together or in combination accounted for $17 \%$ of heterogeneity for end point frequency of mediastinitis, $16.3 \%$ for Gram-positive bacteria, $14.7 \%$ for Gram-negative bacteria, and 23.3\% for MRSA bacteria.

Conclusion: Evidence from this study suggests the importance of latitude of study place and advanced age as risk factors of mediastinitis. Latitude is a marker of thermally regulated bacterial virulence and other local surgical practice. There is concern of increasing risk of mediastinitis and of MRSA in elderly patients undergoing sternotomy.

Keywords: mediastinitis, sternotomy, meta-analysis

\section{Introduction}

The reported incidence of mediastinitis after coronary artery bypass grafting (CABG) is $0.4 \%-4 \% .{ }^{1}$ Mediastinitis is associated with increased morbidity, mortality, and cost.

The etiology and pathophysiology of mediastinitis are complex and multifactorial. Also, mediastinitis carries an excess of long-term risk of mortality over 10 years of follow-up. ${ }^{1,2}$

The variability of incidence of mediastinitis in the literature is due to different study designs, population of patients, surgical cardiac procedures, and geographical area of 
the world with climate and latitude differences. We know that the latitude where the study took place is an important marker for variation in rainfall, humidity, temperature, and environmental mycobacteria that may alter the natural immunity and other factors. Latitude is associated with intensity and duration of sun exposure. Also, ambient temperature and latitude are strongly correlated. ${ }^{3}$ Previous studies have used latitude of study site as proxy for ambient temperature and environmental mycobacteria. ${ }^{4,5}$ We used the same method to assess the etiological role of ambient temperature and mycobacteria on the incidence and microbiology of Helicobacter pylori in a systematic review combined with meta-analysis of the literature. ${ }^{6}$ This systematic review considered worldwide studies of incidence and microbiology of mediastinitis after open-heart surgery.

\section{Materials and methods}

\section{Literature search}

A qualified medical librarian of Medical Library, Oslo University Hospital, was consulted. We searched the Cochrane Central Register of Controlled Trials (1970-2014), Medline/PubMed (1966-2014), and Embase (1980-2014) databases. We used a combination of keywords and details of the search procedure as shown in the Supplementary $\underline{\text { materials. }}$. We used similar strategies to identify previously published meta-analyses and reviews. In addition, we manually searched conference proceedings and textbooks, screened reference lists of all papers, and contacted investigators, experts, and translators. The last update for research was done on August 8, 2014. No limitation on language was considered (Figure 1).

\section{Study selection}

We included prospective and retrospective studies on patients with open-heart surgery coronary artery bypass graft (CABG and valve replacement). Two reviewers independently evaluated reports for eligibility criteria defined as cohort of open-heart surgery patients operated in different centers of the world. Finally, 97 cohorts were considered eligible for the incidence study ${ }^{1,7-102}$ and 63 of them were considered for microbiological incidence of Gram-positive cocci and Gram-negative bacilli and fungi.

\section{Quality assessment of the cohort studies: the component approach}

Unfortunately, there is no agreed "gold standard" appraisal tool for evaluating quality in observational epidemiologic studies, and there are many tools from which to choose. For the purpose

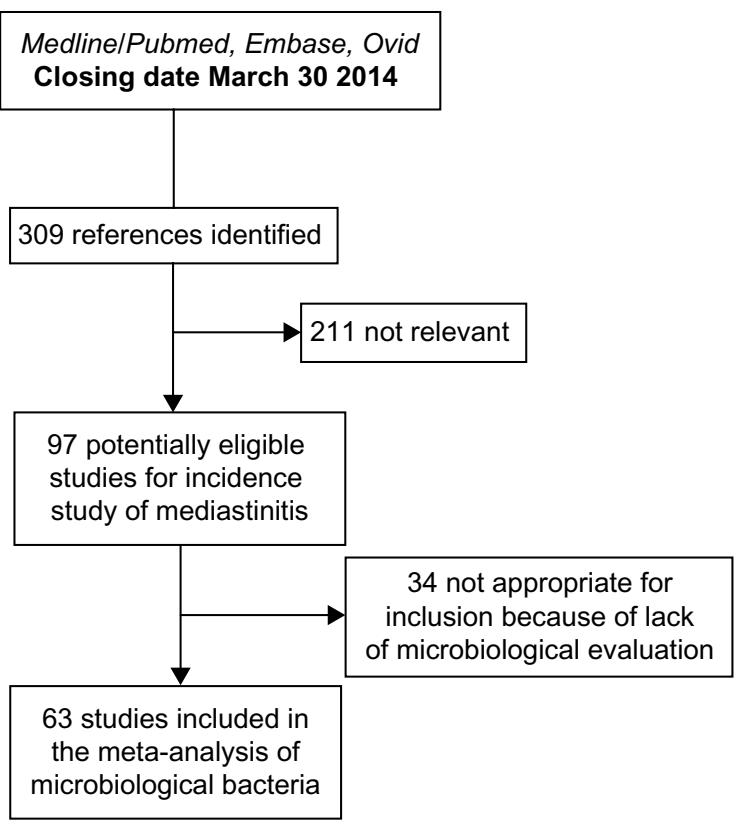

Figure I A flowchart of the literature searches for the systematic review of studies on the incidence of mediastinitis.

of critically appraising cohort studies, we used a checklist based on recommendations by Elwood, ${ }^{103}$ including: a) methods for selecting study participant; b) directionality of the cohort, prospective versus retrospective; and c) enough power to catch the true incidence. The poor reporting on important methodological details may be due to the fact that most papers were published before the STROBE statements. ${ }^{104}$ Sanderson et $\mathrm{al}^{105}$ evaluated a large number of tools for assessing quality of observational epidemiological studies, recommending a simple checklist, including a small number of key domains being specific to the study design under consideration rather than a scale. Scales resulting in numerical summary of quality scores might look simple to use, but such an approach can introduce a bias when assessing study quality. ${ }^{106}$

\section{Data abstraction}

Data regarding publication status, study design, patientrelated characteristics, outcome methods, and results and funding were extracted in duplicate on a standardized form according to an a priori protocol. Authors were contacted for additional data and corrections. Disagreements were resolved by discussion with a third reviewer and subsequent consensus. Patient-related variables were considered in the protocol and included mean age of the cohort, frequency of female sex, and frequency of CABG surgery. The studylevel variables included the nature of the cohort, prospective versus retrospective; latitude and longitude of the place of the study, year of publication, and the presence of adequate 
power. The adequate power was based on the total incidence of deep sternal wound infection (DSWI).

Of the 97 studies, the observed median incidence was $1.5 \%$ and the lower and higher quartile were $0.70 \%$ and $2.3 \%$, respectively. Considering the median of $1.5 \%$ and accepting a precision of $0.8 \%$ (half the interquartile range), we will need a cohort of at least 887 patients to have a $95 \%$ probability to catch this incidence.

\section{End points considered}

The primary end point was the incidence of mediastinitis infection. The diagnosis of post sternotomy mediastinitis was based on the criteria established by the Centres for Disease Control and Prevention. We know that according to Centres for Disease Control and Prevention, surgical site infections can be classified into three categories: superficial incisional sternum superficial infections (SSIs; involving only skin and subcutaneous tissues), deep incisional SSIs (involving deep soft tissue), and organ/space SSIs (involving any part of the body other than the incision itself), which is opened or manipulated during the operative procedure. The definition of mediastinitis must meet at least one of the following criteria: 1) positive bacterial culture from the mediastinal space; 2) evidence of mediastinitis during surgery or histology; or 3) one of the following: fever $\left(>38^{\circ} \mathrm{C}\right)$, chest pain, sternal instability, purulent discharge from the mediastinal area, organisms cultured from blood or from discharge of the mediastinal area, or mediastinal widening in radiology.

Unfortunately, in the literature, various terms for chest SSIs have been used, including sternal infection, deep sternal infection, and major infection. The inconsistent definitions could create misclassification of mediastinitis.

Secondary end points were the incidence of different microorganisms recovered in mediastinitis secondary to cardiovascular surgery. They included: 1) Gram-positive cocci (Staphylococcus aureus including methicillin-resistant $S$. aureus [MRSA], Staphylococcus epidermis, and Enterococcus spp); 2) Gram-negative bacilli (Esherichia coli, Enterobacter spp., Klebsiella spp., Proteus spp., and other Enterobacteriaceae and Pseudomonas spp.); 3) fungi (Candida albicans and others); and 4) polymicrobial mediastinitis (mixed Grampositive and Gram-negative organisms account for $>10 \%$ ). Other microorganisms were occasionally reported.

\section{Quantitative data synthesis}

\section{Statistical pooling}

Random-effects meta-analysis of single proportions was considered to estimate a cumulative incidence. The
DerSimonian-Laird estimate ${ }^{107}$ is used in the random-effects model. To obtain summary measures, we used random-effects model due to the large heterogeneity of the results. To pool the incidence measures, logit transformation and sometimes logarithm transformation were initially performed to handle the distribution asymmetry. Sometimes, we considered the Freeman-Tukey double arcsine transformation of the proportions to calculate an overall pooled proportion and to stabilize the variance. ${ }^{108}$ These incidences were weighted by the inverse variance. When using the logit transformation, a continuity correction was applied if any studies had a zero cell count. By default, 0.5 is added to all cell frequencies of studies with a zero cell count. For individual studies, the Clopper-Pearson confidence interval was estimated. ${ }^{109}$

\section{Sources of heterogeneity, evaluation, and quantification}

Statistical heterogeneity among studies was assessed with Cochran's $Q$ test. The magnitude of heterogeneity was evaluated by the $I^{2}$ statistics, which describes the proportion of total variation due to heterogeneity rather than chance. ${ }^{110} \mathrm{In}$ order to investigate possible sources of heterogeneity, two different methods were used: subgroup analyses and metaregression. We stratified our data according to the following study characteristics: nature of the cohort, prospective versus retrospective, and presence of a priori power estimation for the study.

A random-effects model was used to combine subgroups with separate estimate of $\tau^{2} .{ }^{110}$ After doing the subgroup analyses, we ran a random-effect meta-regression analysis, where the outcome variable was the transformated observed incidence from every study, indicating effect and study-level and patient-level characteristics (covariates). This randomeffect regression model was done to enable exploration of the source of heterogeneity in the association between incidence of DWSI and covariates. The mixed model is an extension of the random-effect model. In this model, some heterogeneity is explained by moderators (covariates) and the rest by the random-effect term.

\section{Publication bias or small-study effect}

In order to assess potential publication bias or small-study effect, we used the funnel plot, which is a good visual evaluation of sampling bias or small-study effect.

\section{Begg and Mazumdar rank correlation test}

Begg and Mazumdar ${ }^{111}$ suggested a test statistics based on rank correlation between standardized outcome estimates and 
variance estimates of estimated outcome effect. Kendall's tau is used as a correlation measure. The test statistics follows a standard normal distribution.

\section{Egger's test of asymmetry}

Another test of asymmetry (Egger's test) ${ }^{112}$ applied on the funnel plot was performed. The test statistics is based on a weighted linear regression of the treatment effect on its standard error. The test statistics follows a normal distribution with number of studies -2 as degrees of freedom. Nowadays, Egger's test is mostly seen as a test of small-study effects.

\section{Detection and correction for publication bias/small-} study effect using the trim and fill method

Publication bias is a serious issue, as it may lead to biased estimates, which appears to be precise. A popular method for detecting and adjusting bias is the trim and fill method. ${ }^{113}$ When there is substantial heterogeneity, the trim and fill method is inappropriate to control for publication bias. ${ }^{114}$

\section{Power considerations in meta-analysis and meta-regression}

The test of funnel plot asymmetry and meta-regression analysis can be used only when at least ten studies are included in the meta-analysis because of power limitations. As underlined by Borenstein et $\mathrm{al}^{110}$ under the fixed model, the number of subjects in the studies and the effect size we need to pinpoint determine the power of the meta-analysis. Under the randomeffect model, power is a function of not only the total number of subjects but also the number of studies, the effect size, and the variance between studies (heterogeneity).

For power consideration, we used a minimum of ten studies per covariate in a multivariate model of meta-regression. On the other hand, it is well known that aggregate variables (patient-related variables) are subject to ecological fallacy and must be considered only as hypothesis generating.

All statistical analyses were performed using the R package meta ${ }^{115}$ and Stata 13.0. ${ }^{116}$ We have followed the Preferred Reporting Items for Systematic Reviews and Meta-Analyses guidelines for meta-analyses and systematic reviews of observational studies in the present report. ${ }^{117}$

\section{Results}

\section{Trial flow}

After identifying 309 references, 211 were excluded due to irrelevant content and duplicate publications, leaving 97 potentially eligible studies for incidence of mediastinitis. From these 97 eligible studies, 63 studies had microbiological evaluation. Finally, 97 studies were included in our systematic review of incidence and 63 for microbiological specific bacteria (Figure 1).

\section{Study characteristics}

The study characteristics considered were the place and latitude of the study, the year of publication, the mean age of the study population, frequency of female patients, frequency of isolated $\mathrm{CABG}$, the prospective or retrospective nature of the cohort design, and the adequacy of power of the study.

\section{End point total incidence of DSWI or mediastinitis}

A total of $1,420,845$ patients were included in the 97 studies, and the number of patients with DSWI or mediastinitis was 13,662 . The mean age was 62.24 years ( $n=61$ studies) with a range from 51 years to 67.9 years. The frequency of female patients was $28.2 \%$ with a range from $1 \%$ to $75 \%$ ( $n=68$ studies). Mean frequency of CABG was $81.1 \%(n=61$ studies) with a range from $36.6 \%$ to $100 \%$. For the studylevel characteristics, all the studies had a cohort design with 59 prospective and 48 retrospective. Of the total $97(85.7 \%)$ studies, 84 were adequately powered.

\section{End point bacteriology (incidence of microorganisms)}

Only 63 of 97 studies have performed microbiological analysis and reported their results. Considering these studies, the number of patients included was 306,440 and the number of microorganisms (bacteria and fungi) was 3,724. The

Table I Incidence of microorganisms recovered in mediastinitis secondary to cardiothoracic surgery with frequency in 63 cohort studies

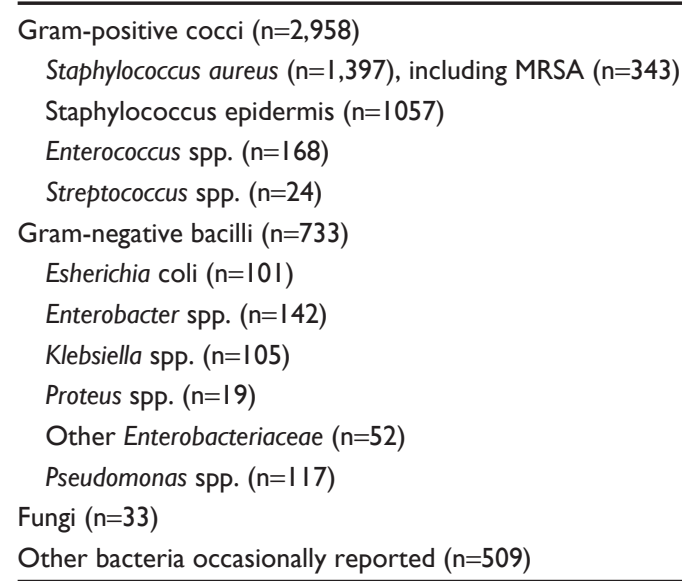

Note: Total number of microorganisms (bacteria + fungi) is 3,724 in 306,440 patients.

Abbreviation: MRSA, methicillin-resistant Staphylococcus aureus. 
total number of Gram-positive cocci was $n=2,958(77.3 \%)$, including 343 MRSA microorganisms. Gram-negative bacilli represented 733 microorganisms, and the number of fungi infections was 33 (Table 1).

\section{Quantitative data synthesis}

End point incidence of DSWI (mediastinitis) in 97

\section{studies worldwide}

The summarized pooled estimate incidence of DSWI in the 97 studies using the random-effect model was 0.0158 (95\% CI 0.0142-0.0175) with a substantial heterogeneity (Tables 2 and 3).

The funnel plot in Figure 2 visually showed evidence of bias and small-study effect. This was verified using Begg and Mazumdar rank correlation test and confirmed by the Egger's test, which had a $P$-value of 0.001 accepting the null hypothesis of small-study effect. Because of substantial heterogeneity, we did not correct for selection bias considering the trim and fill simulation method.

The presence of heterogeneity led us to an investigation of its origin. A stratification analysis on the prospective versus retrospective nature of the cohorts, the adequacy of powered studies versus power-deficient studies, and the median latitude of the place of the studies showed a significant difference between subgroups. We extended the analyses with a metaregression model taking into account moderator variables such as mean age, frequency of CABG in the total open-heart surgery, frequency of female patients, and latitude. One important study-level variable identified was latitude (Figure 3) with decreasing incidence of mediastinitis with increasing latitude. There was an increasing incidence of DSWI with the increasing age of patient at sternotomy (Figure 4).

Table 2 Estimate of incidence of mediastinitis with stratification on prospective nature and power of the cohort and on latitude of the study place using the random-effect model

\begin{tabular}{|c|c|c|c|c|c|}
\hline Subdivision & $\mathbf{n}$ & Incidence $(95 \% \mathrm{CI})$ & $\tau^{2}$ & $I^{2}(\%)$ & $P_{\text {-value }}{ }^{a}$ \\
\hline All studies & 97 & $0.0158(0.0142-0.0175)$ & 0.0039 & 97.8 & \\
\hline \multicolumn{6}{|c|}{ Prospective cohort design } \\
\hline Yes & 49 & $0.02(0.016-0.024)$ & 0.0075 & 97.3 & $<0.0001$ \\
\hline No/Unclear & 48 & $0.012(0.010-0.015)$ & 0.0019 & 95.7 & \\
\hline \multicolumn{6}{|c|}{ Powered study } \\
\hline Yes & 82 & $0.0146(0.013-0.016)$ & 0.0036 & 98 & 0.021 \\
\hline No & 15 & $0.0274(0.0158-0.015)$ & 0.0225 & 93.1 & \\
\hline \multicolumn{6}{|c|}{ Latitude over median 40.7 I } \\
\hline Yes & 49 & $0.0126(0.0112-0.014)$ & 0.0016 & 96.4 & 0.0001 \\
\hline No & 48 & $0.0199(0.0162-0.024)$ & 0.009 & 97.7 & \\
\hline
\end{tabular}

Note: ${ }^{a}$ Test for subgroup differences using the random-effect model between groups with $Q$ statistics, $d f=I$, and $P$-value.

Abbreviations: $\mathrm{Cl}$, confidence interval; $\tau^{2}$, interstudy variability; df, degree of freedom.
Table 3 Meta-regression between incidence of mediastinitis and the different study-level and patient-level variables in a univariate analysis

\begin{tabular}{llllll}
\hline Covariates & Level & $\boldsymbol{\beta}$-coefficient & SE $(\boldsymbol{\beta})$ & $\boldsymbol{Z}$ & $\boldsymbol{P}$-value \\
\hline Latitude & Degrees & -0.0020 & 0.0007 & -2.67 & 0.0075 \\
Age & Years & 0.0068 & 0.0029 & 2.35 & 0.018 \\
Female sex & Percent & 0.0003 & 0.0008 & 0.4367 & 0.6623 \\
CABG & Percent & 0.0006 & 0.005 & 1.20 & 0.2029 \\
Publication year & Year & 0.0010 & 0.0006 & 1.63 & 0.1023 \\
\hline
\end{tabular}

Abbreviations: $\mathrm{SE}$, standard error; $\mathrm{CABG}$, coronary artery bypass grafting.

A multivariate meta-regression was performed, which considered study-level and patient-level variables together. This, using random- and mixed-effect models, identified the presence of prospective design, age of the patient, and the latitude of the study as risk factors of DSWI, with $17 \%$ of heterogeneity accounted for by these three variables together.

\section{End points incidence of microorganisms recovered in} mediastinitis

\section{Gram-positive cocci}

Tables 4 and 5 summarize the pooled estimate incidence of Gram-positive cocci in 63 studies using the random-effect model. The incidence was $0.009,95 \%$ CI (0.0081-0.0121), with a substantial heterogeneity. The funnel plot visually showed evidence of bias and small-study effect. This was confirmed by the Begg and Mazumdar rank correlation test ( $P=0.018)$ and by the Egger's test, which had a $P$-value of 0.006 accepting the null hypothesis of small-study effect or selection bias. Because of substantial heterogeneity, we did not correct for selection bias considering the trim and fill simulation method.

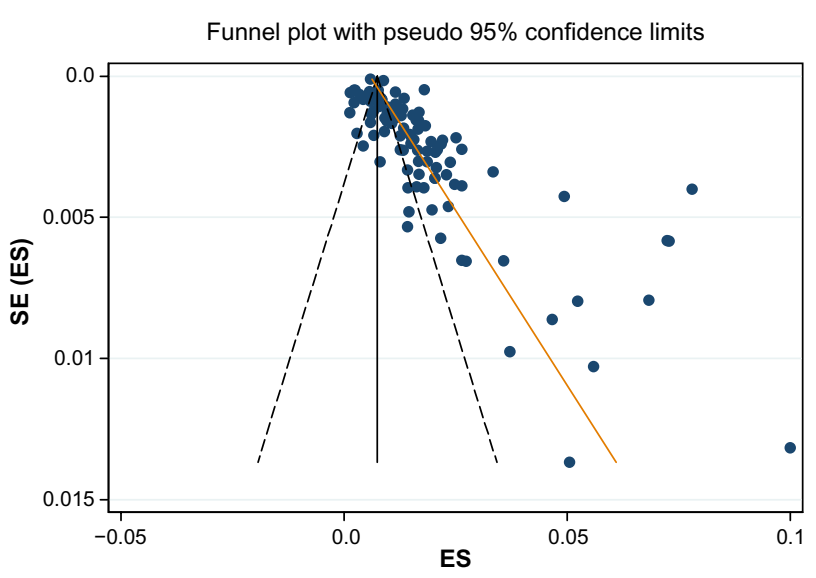

Figure 2 A funnel plot for the incidence of mediastinitis in 97 studies with Egger line. Abbreviations: SE, standard error; ES, effect size. 


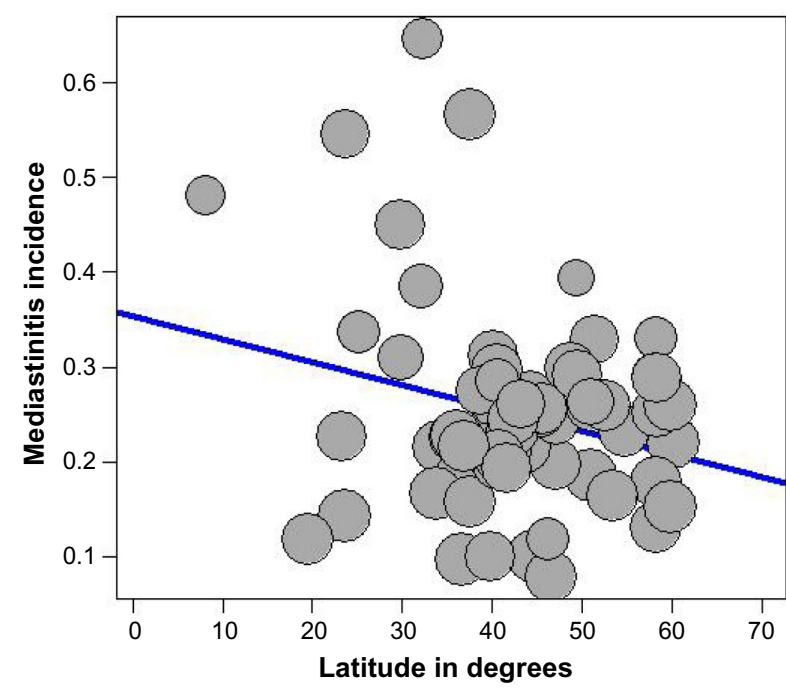

Figure 3 Meta-regression of incidence of mediastinitis and latitude of study place. Note: Freeman-Tukey double arcsine transformated incidence.

The presence of heterogeneity led us to an investigation of its origin. A stratification analysis on the prospective versus retrospective nature of the cohort and the median latitude of the place of the study showed a significant difference between subgroups. When we extended the analyses with a mixedeffect meta-regression model, one important patient-related variable was identified: age of the patient at sternotomy, with increasing incidence of Gram-positive cocci with increasing age. A multivariate meta-regression was performed, which considered study-level and patient-level variables together. The multivariate mixed-effect model identified age and the prospective nature of the cohort as risk factors of Grampositive cocci with $16.3 \%$ of heterogeneity accounted for by these two variables together.

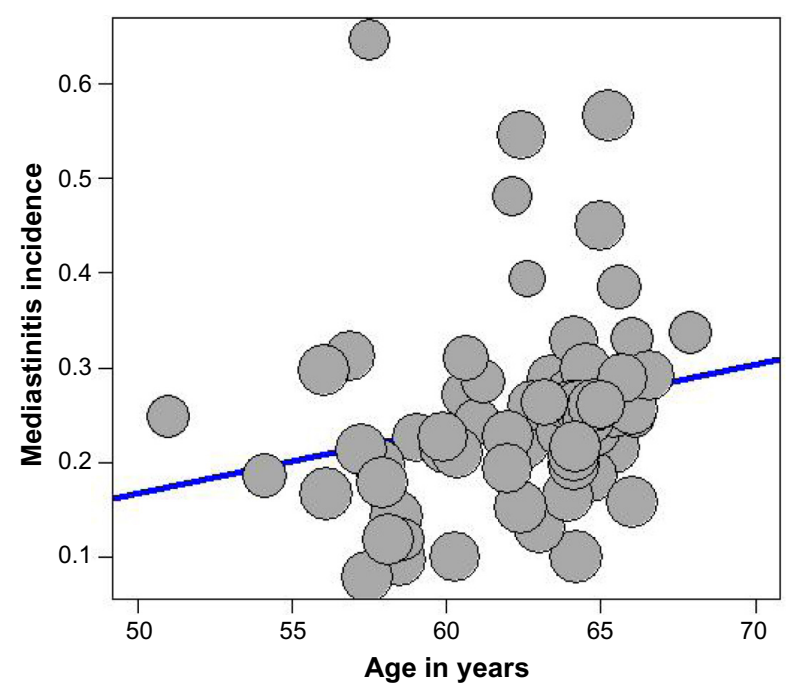

Figure 4 Meta-regression of incidence of mediastinitis and mean age of the patient. Note: Freeman-Tukey double arcsine transformated incidence.
Table 4 Estimate of incidence of Gram-positive cocci with stratification on prospective nature of the cohort and latitude of the study place using the random-effect model

\begin{tabular}{llllll}
\hline Subdivision & $\mathbf{n}$ & Incidence $(\mathbf{9 5 \%} \mathbf{~ C l})$ & $\tau^{2}$ & $I^{2}(\%)$ & P-value $^{\mathbf{a}}$ \\
\hline All studies & 63 & $0.009(0.008 I-0.012 I)$ & 0.6067 & 96.6 & \\
$\begin{array}{l}\text { Prospective } \\
\text { Yes }\end{array}$ & 33 & $0.012(0.0095-0.0167)$ & 0.6219 & 96.6 & 0.0078 \\
No/Unclear & 30 & $0.007(0.0062-0.0097)$ & 0.3392 & 93.4 & \\
Latitude over median & $\mathbf{4 0}$ & & & \\
Yes & 32 & $0.009(0.007-0.012)$ & 0.3894 & 95.7 & 0.8897 \\
No & 31 & $0.0101(0.007 I-0.0144)$ & 0.964 & 97.0 & \\
\hline
\end{tabular}

Note: ${ }^{\text {TT}}$ Test for subgroup differences using the random-effect model between groups with $\mathrm{Q}$ statistics, $\mathrm{df}=\mathrm{I}$, and $P$-value.

Abbreviations: $\mathrm{Cl}$, confidence interval; $\tau^{2}$, interstudy variability.

\section{Methicillin-resistant S. aureus}

Tables 6 and 7 summarize the pooled estimate incidence of MRSA in 63 studies using the random-effect model. The incidence was $0.0008,95 \%$ CI $(0.0005-0.0012)$, with a substantial heterogeneity. The funnel plot visually showed evidence of bias and small-study effect. This was confirmed by the Begg and Mazumdar rank correlation test with continuity correction $(P=0.0007)$ and by the Egger's test, which had a $P$-value of 0.0128 accepting the null hypothesis of small-study effect or selection bias. Because of substantial heterogeneity, we did not correct for selection bias considering the trim and fill simulation method.

The presence of heterogeneity led us to an investigation of its origin. A stratification analysis on the prospective versus retrospective nature of the cohort and the median latitude of the place of the study showed a significant difference between subgroups. When we extended the analyses with a mixedeffect meta-regression model, one important study-level variable was identified: the latitude of the place of the study, with decreasing incidence of MRSA with increasing latitude (Figure 5). Also, we identified increasing incidence of MRSA with increasing age of the patients (Figure 6). A multivariate meta-regression was performed, which considered study-level and patient-level variables. The multivariate using mixedeffect meta regression model identified latitude and age of the

Table 5 Meta-regression model between incidence of Grampositive cocci and the different study-level and patient-level variables in a univariate analysis using the 63 cohorts

\begin{tabular}{llllll}
\hline Covariates & Level & $\boldsymbol{\beta}$-coefficient & SE $(\boldsymbol{\beta})$ & $\boldsymbol{Z}$ & $\boldsymbol{P}$-value \\
\hline CABG & Percent & 0.0110 & 0.0058 & 1.89 & 0.057 \\
Age & Years & 0.0889 & 0.0429 & 2.07 & 0.038 \\
Latitude & Degrees & -0.0050 & 0.0084 & 0.596 & 0.5508 \\
Female sex & Yes/No & 0.0029 & 0.0085 & 0.342 & 0.7315 \\
Publication year & Year & 0.0012 & 0.0010 & 1.80 & 0.2378 \\
\hline
\end{tabular}

Abbreviations: SE, standard error; CABG, coronary artery bypass grafting. 
Table 6 Estimate of total incidence of MRSA with stratification on prospective nature of cohort and latitude of the study place using the random-effect model

\begin{tabular}{lcclll}
\hline Subdivision & $\mathbf{n}$ & Incidence $(\mathbf{9 5 \%} \mathbf{C l})$ & $\tau^{2}$ & $\boldsymbol{I}^{\mathbf{2}}(\%)$ & $\boldsymbol{P}_{\text {-value }}$ \\
\hline All studies & 63 & $0.0008(0.0005-0.0012)$ & 1.79 & 90.5 & \\
$\begin{array}{l}\text { Prospective } \\
\text { Yes ohort design }\end{array}$ & 33 & $0.0012(0.0007-0.002)$ & 1.816 & 91.5 & 0.0417 \\
No/Unclear & 30 & $0.0005(0.0004-0.0009)$ & 1.419 & 83.2 & \\
Latitude over median & $\mathbf{4 0}$ & & & \\
Yes & 32 & $0.0006(0.0003-0.0010)$ & 1.34 & 84 & 0.0853 \\
No & 31 & $0.0011(0.0006-0.002 I)$ & 1.90 & 84 &
\end{tabular}

Notes: ${ }^{\mathrm{T}}$ Test for subgroup differences using the random-effect model between groups with $\mathrm{Q}$ statistics, $\mathrm{df}=\mathrm{I}$, and $P$-value.

Abbreviations: MRSA, methicillin-resistant Staphylococcus aureus; $\mathrm{Cl}$, confidence interval; $\tau^{2}$, interstudy variability; $\mathrm{df}$, degree of freedom.

patient as independent risk factors of MRSA with $23.13 \%$ of heterogeneity accounted for by these two variables together.

\section{Gram-negative bacilli}

Tables 8 and 9 summarize the pooled estimate incidence of Gram-negative bacilli in 63 studies using the random-effect model. The incidence was $0.0024,95 \%$ CI (0.0018-0.032), with a substantial heterogeneity. The funnel plot visually showed evidence of bias and small-study effect. The Begg and Mazumdar rank correlation test confirmed this with continuity correction $(P=0.037)$ and by the Egger's test, which had a $P$-value of 0.00061 accepting the null hypothesis of small-study effect or selection bias. Because of substantial heterogeneity, we did not correct for selection bias considering the trim and fill simulation method.

The presence of heterogeneity led us to an investigation of its origin. A stratification analysis on the prospective versus retrospective nature of the cohort and the median latitude of the place of the study showed a significant difference between subgroups. When we extended the analyses with a mixed-effect meta-regression model, one important study-level related variable was identified: the latitude of the place of the study, with decreasing incidence of Gram-negative bacilli with increasing latitude. A multi-

Table 7 Meta-regression model between incidence of MRSA and the different study-level and patient-level variables in a univariate analysis using the 63 cohorts

\begin{tabular}{llllll}
\hline Covariates & Level & $\beta$-coefficient & SE $(\boldsymbol{\beta})$ & $\boldsymbol{Z}$ & $\boldsymbol{P}$-value \\
\hline CABG & Percent & 0.007 & 0.005 & 1.32 & 0.1848 \\
Age & Years & 0.0079 & 0.0031 & 2.53 & 0.0112 \\
Latitude & Degrees & -0.0016 & 0.0006 & -2.53 & 0.0114 \\
Female sex & Yes/No & -0.0005 & 0.0007 & -0.78 & 0.4345 \\
Year of publication & Year & 0.0140 & 0.0227 & 0.61 & $0.538 \mathrm{I}$ \\
\hline
\end{tabular}

Abbreviations: MRSA, methicillin-resistant Staphylococcus aureus; SE, standard error; CABG, coronary artery bypass grafting.

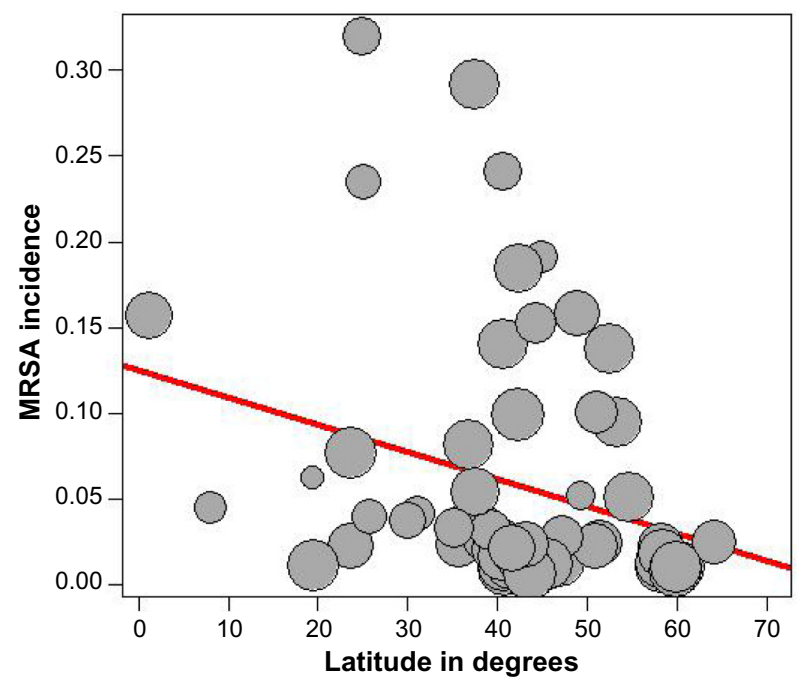

Figure 5 Meta-regression of incidence of MRSA and latitude of the study place. Note: Freeman-Tukey double arcsine transformated incidence.

Abbreviation: MRSA, methicillin-resistant Staphylococcus aureus.

variate meta-regression was performed, which considered study-level variables also. The multivariate mixed-effect regression model identified latitude and the prospective nature of the cohort as risk factors of Gram-negative bacilli with $14.7 \%$ of heterogeneity accounted for by these two variables together.

\section{Discussion}

Our systematic review and meta-analysis of cohorts estimating incidence of DSWI and incidence of different microorganisms after sternotomy showed a high degree of heterogeneity among cohorts for all the outcomes. Also, publication bias or small-size effect was found to influence the outcomes.

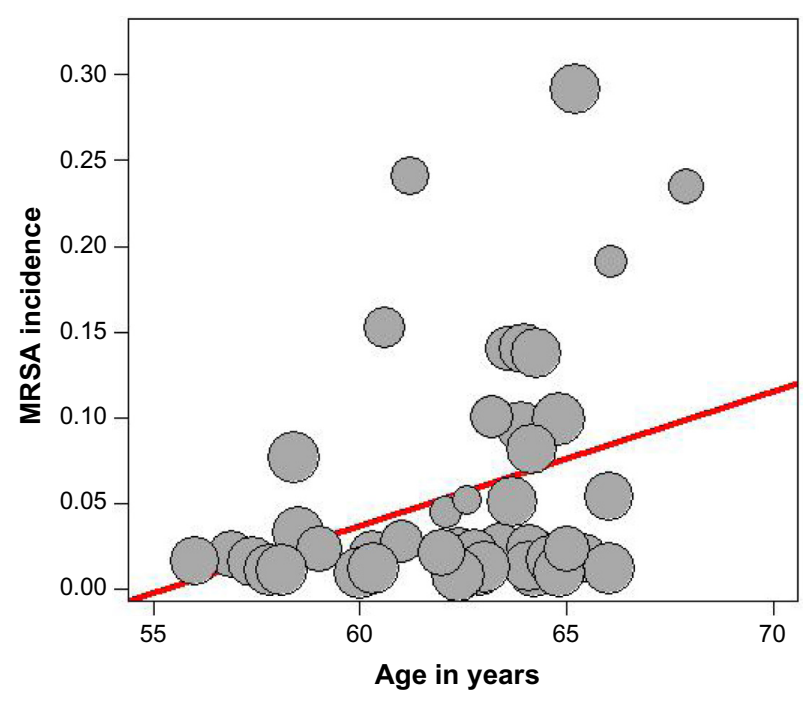

Figure 6 Meta-regression of incidence of MRSA and mean age of the patient. Note: Freeman-Tukey double arcsine transformated incidence. Abbreviation: MRSA, methicillin-resistant Staphylococcus aureus. 
Table 8 Estimate of total incidence of Gram-negative bacilli with stratification on prospective nature of cohort and latitude of the study place using the random-effect model

\begin{tabular}{llllll}
\hline Subdivision & $\mathbf{n}$ & Incidence $(\mathbf{9 5 \%} \mathbf{C l})$ & $\tau^{\mathbf{2}}$ & $\boldsymbol{I}^{\mathbf{2}}(\%)$ & P-value $^{\mathbf{a}}$ \\
\hline All studies & 63 & $0.0024(0.0018-0.0032)$ & 0.9819 & 91.8 & \\
$\begin{array}{l}\text { Prospective cohort design } \\
\text { Yes }\end{array} \quad 35$ & $0.0058(0.0053-0.0063)$ & 0.8591 & 91.9 & 0.0001 \\
No/Unclear & 30 & $0.0039(0.0034-0.0043)$ & 1.2000 & 91.4 & \\
Latitude over median & $\mathbf{4 0}$ & & & \\
Yes & 32 & $0.0018(0.0012-0.0025)$ & 0.6549 & 87.4 & 0.008 \\
No & 31 & $0.0036(0.0024-0.0054)$ & 1.046 & 92.4 & \\
\hline
\end{tabular}

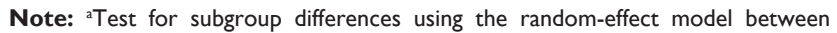
groups with $Q$ statistics, $d f=I$, and $P$-value.

Abbreviations: $\mathrm{Cl}$, confidence interval; $\tau^{2}$, interstudy variability; df, degree of freedom.

Meta-regression analyses indicated that heterogeneity could be explained by patient-related variables and study-level characteristics. For studies reporting on DSWI, the latitude of the study place and age of the patients were important determinants of incidence of this complication. Our results do not support the importance of CABG compared with valve replacement or sex of the patients as associated with incidence of DSWI. Determinants of Gram-positive cocci, including MRSA and Gram-negative bacilli microorganisms, are different. Also, latitude of the study place and age of the patients were determinants for the incidence of MRSA.

\section{Strengths and limitations}

Our review is based on a broad literature search, and it seems unlikely that we have missed relevant studies. Study selection and data extraction, including data assessment, were done by two authors to minimize bias and transcription errors. ${ }^{118}$ The major limitation of our study is the quality of cohort studies; it is clear that there is bias introduced by retrospective cohort design. The prospective cohorts showed higher incidence of mediastinitis and specific microorganisms. In the retrospective cohort studies, the accuracy of the parameters recorded and the quality of wound surveillance are therefore variable.

Table 9 Meta regression model between incidence of Gramnegative bacilli and the different study-level and patient-level variables in a univariate analysis using the 63 cohorts

\begin{tabular}{llllll}
\hline Covariates & Level & $\beta$-coefficient & SE $(\boldsymbol{\beta})$ & $\boldsymbol{Z}$ & $\boldsymbol{P}_{\text {-value }}$ \\
\hline Latitude & Degrees & -0.0330 & 0.0108 & -3.07 & 0.002 \\
Age & Years & -0.0466 & 0.0585 & -0.79 & 0.4261 \\
Female sex & PCT & 0.0173 & 0.0126 & 1.36 & 0.1711 \\
CABG & PCT & 0.0067 & 0.0087 & 0.76 & 0.4423 \\
Publication year & Year & -0.0092 & 0.0138 & -0.66 & 0.5055 \\
\hline
\end{tabular}

Note: ${ }^{a}$ Test for subgroup differences using the random-effect model between groups with $\mathrm{Q}$ statistics, $\mathrm{df}=\mathrm{I}$, and $P$-value.

Abbreviations: SE, standard error; CABG, coronary artery bypass grafting; PCT, percentage; $\mathrm{df}$, degree of freedom.
The second problem is a misclassification of the end points DSWI, with some studies pooling DSWIs with infections at other sites, superficial sternal wound infections, or sternal and mechanical complications. Most importantly, all these studies are from different centers. It is likely that selection of patients, choice of procedures, and management of the perioperative period vary greatly among cardiac surgical units. These parameters, although difficult to record, may be important determinants of DSWI. Prospective multicentre studies would ascertain DSWI and identify high-risk patients and procedures and protect cohorts against attrition bias (dropout and loss to follow-up). Another limitation was the impossibility to control the small-study effect due to substantial heterogeneity. Finally, underpowered designed cohorts represented another limitation of our study.

\section{Problem of heterogeneity due to patient- level and study-level variables on the incidence of mediastinitis and specific microorganisms}

Latitude of the place of the study and temperatureregulated bacterial virulence

Latitude of the study site is a proxy and marker of rainfall, humidity, and environmental mycobacteria that may alter the natural immunity. Latitude and temperature are correlated. ${ }^{4}$

As it was underlined by Shapiro and Cowen ${ }^{119}$ for diverse microbial species including viruses, bacteria and fungi temperatures represent a critical environmental factor that is well established. It has been known for some time that temperature is a critical environmental trigger for many bacterial species. ${ }^{119}$

Also, temperature influences developmental transitions in the human fungal pathogen C. Albicans's morphogenetic transition between yeast and filamentous growth and resistance to antifungal drugs.

Eber et al, ${ }^{120}$ with data from 132 US hospitals in the period 1999-2006, found that summer season and higher mean monthly outdoor temperature were associated with substantial increases of bloodstream infection. There were increases in monthly count of $S$. aureus including MRSA and other Gram-negative bacteria such as E. coli and Acinetobacter. This study focused on blood culture to ensure that blood culture reflects infection and not merely colonizing organisms and that the association is with monthly bacterial count and monthly mean temperature, total precipitation, and mean relative humidity. There are several potential explanations of frequency of bacterial bloodstream infections 
compared with outdoor temperature levels. First, relatively higher temperatures not $>37^{\circ} \mathrm{C}$ may facilitate increased growth of bacteria in the environment, which may, in turn, increase colonization of humans.

Mechanisms of bacterial growth and optimal growth temperature vary by organism, which may explain the observed difference in association with outdoor temperature between organisms.

Investigators Mermel et $\mathrm{al}^{121}$ have observed peaks of community-associated MRSA during summer and autumn and its association with seasonal skin infections. It is well known that each infection agent has an optimal temperature for growth; most grow best at temperature close to $37^{\circ} \mathrm{C}$, and too low or too high temperature will not promote growth. Sahoo et al ${ }^{122}$ in a time series analysis showed that a combination of weekly average maximum temperature above $33^{\circ} \mathrm{C}$ coinciding with weekly average relative humidity ranging between $55 \%$ and $78 \%$ is most favorable for occurrence of skin and soft tissue infections due to $S$. aureus and MRSA, and within these parameters, each unit increase in occurrence of MRSA was associated with increase in weekly average temperature of $1.7^{\circ} \mathrm{C}$ and weekly average relative humidity of $10 \%$.

Another experimental work done by Madiraju et al ${ }^{123}$ challenging MRSA strains in exponential phase cultures by methicillin observed that growth and peptidoglycan synthesis were much more resistant at $30^{\circ} \mathrm{C}$ than $40^{\circ} \mathrm{C}$.

\section{Latitude of the study place as a marker of surgical and other local practices}

The latitude of the place of the study is a marker of operating room practices in open-heart surgery. Surgical procedures as risk factors of mediastinitis were investigated extensively by Eklund et al. ${ }^{27}$ The risk of infection in the operating theater is dependent on a lot of factors. One of them the beneficial effect of a preoperative antiseptic shower for reducing the microbial colony count on the patient's skin is still controversial on lowering the infection rate. ${ }^{124}$ Shaving the hair from the incision site, especially the night before surgery, is still controversial. ${ }^{72,125}$ A Cochrane collaboration review in $2011^{126}$ concluded that when it is necessary to remove hair, the existence evidence suggests that clippers are associated with fewer surgical site infections than razors.

In diabetic patients, during cardiopulmonary bypass, a peak core body temperature $>37.9 \mathrm{C}$ could increase the risk of mediastinitis postoperatively as underlined by Groom et al. ${ }^{127}$

The air contamination control in the operating room ${ }^{128}$ is important as contamination of the sternal wound was reduced by $46 \%$, pinpointed by Verkkala et al. ${ }^{128}$
High incidence of glove perforation rates $(26 \%-40 \%)$ was found after sternotomy. ${ }^{129,130}$

Also, an incidence of $36 \%$ of surgeons' fingertips was contaminated by Gram-positive bacteria. ${ }^{131}$ High prevalence of skin recolonization at the end of surgery was highlighted. ${ }^{129}$

There is variability in regimens of antimicrobial prophylaxis throughout the world. Nowadays, the effectiveness of these regimens in reducing SSI is falling short of standard, ${ }^{132,133}$ and there is increasing incidence of multiresistant bacteria worldwide.

\section{Elderly patient and increasing risk of mediastinitis and MRSA}

Age of the patients was associated with increasing incidence of total mediastinitis and incidence of specifically Grampositive bacteria, including MRSA. The elderly patients are a population of people who have a long history of using antibiotics in previous time and have acquired some resistance to these drugs. Suffering from a weakened immune system, the elderly patients are particularly susceptible to all infections, especially MRSA.

In a population study in overall Sweden, ${ }^{134}$ the incidence of MRSA per 100,000 inhabitants during the period of 2000-2003 was constant with $\sim 5$ cases/100,000 inhabitants of 1-59 years and suddenly increased to 10 cases/100,000 inhabitants between 60 and 79 years and to 20 cases/100,000 inhabitants $>80$ years. This study showed the same trend of increasing incidence by age as in our study on a population of open-heart operated patients.

Elderly patients have high frequency of infectious diseases such as influenza, pneumonia, and urinary tract infection with difficulties in performing early diagnosis because the usual symptoms such as fever and leukocytosis are missing and they are on a high risk of mortality. Little effectiveness of antibiotic treatment in the elderly patients has been shown. On the other hand, there is an alarming upsurge nowadays of antibiotic-resistant bacteria such as MRSA in the community and hospitals and old-people's home institutions.

This strong association between MRSA and mortality among elderly patients is making preventive actions and politics mandatory and of paramount importance. Nowadays, MRSA is a serious threat to public health throughout the world and to the early and long-term outcome of open-heart surgery.

\section{Conclusion}

Evidence from this study suggests the importance of latitude of study place and advanced age as risk factors of 
mediastinitis. Latitude is a marker of thermally regulated bacterial virulence and variability of surgical and local practices in open-heart surgery in different places of the world. There is deep concern for the high incidence of mediastinitis and MRSA in the elderly patients undergoing sternotomy, and there is urgent need of preventive action.

\section{Author contributions}

All authors contributed toward data analysis, drafting and critically revising the paper and agree to be accountable for all aspects of the work.

\section{Acknowledgment}

We would like to thank our Medical Librarian, Marie Isachsen, for assisting in the literature search.

\section{Disclosure}

The authors report no conflicts of interest in this work.

\section{References}

1. Risnes I, Abdelnoor M, Almdahl SM, Svennevig JL. Mediastinitis after coronary artery bypass grafting risk factors and long-term survival. Ann Thorac Surg. 2010;89(5):1502-1509.

2. Risnes I, Abdelnoor M, Veel T, Svennevig JL, Lundblad R, Rynning SE. Mediastinitis after coronary artery bypass grafting: the effect of vacuum-assisted closure versus traditional closed drainage on survival and re-infection rate. Int Wound J. 2014;11(2):177-182.

3. Strahler AH, Strahler AN. Physical Geography: Science and Systems of the Human Environment. New York: Third Wiley; 2005:256-282.

4. Colditz GA, Brewer TF, Berkey CS, et al. Efficacy of BCG vaccine in the prevention of tuberculosis. Meta-analysis of the published literature. JAMA. 1994;271(9):698-702.

5. Cheng JY, Ko JS, Chen RY, Ng EM. Meta-regression analysis using latitude as moderator of paternal age related schizophrenia risk: high ambient temperature induced de novo mutations or is it related to the cold? Schizophr Res. 2008;99(1-3):71-76.

6. Sandven I, Abdelnoor M, Nesheim BI, Melby KK. Helicobacter pylori infection and hyperemesis gravidarum: a systematic review and meta-analysis of case control studies. Acta Obstet Gynecol Scand. 2009;88:1190-1200.

7. Abboud CS, Wey SB, Baltar VT. Risk factors for mediastinitis after cardiac surgery. Ann Thorac Surg. 2004;77(2):676-683

8. Ahmed D, Cheema FH, Ahmed YI, et al. Incidence and predictors of infection in patients undergoing primary isolated coronary artery bypass grafting: a report from a tertiary care hospital in a developing country. J Cardiovasc Surg (Torino). 2011;52(1):99-104.

9. Alserius T, Anderson RE, Hammar N, Nordqvist T, Ivert T. Elevated glycosylated haemoglobin $(\mathrm{HbA} 1 \mathrm{c})$ is a risk marker in coronary artery bypass surgery. Scand Cardiovasc J. 2008;42(6):392-398.

10. Antunes PE, Bernardo JE, Eugénio L, de Oliveira JF, Antunes MJ. Mediastinitis after aorto-coronary bypass surgery. Eur J Cardiothorac Surg. 1997;12(3):443-449.

11. Ariyaratnam P, Bland M, Loubani M. Risk factors and mortality associated with deep sternal wound infections following coronary bypass surgery with or without concomitant procedures in a UK population: a basis for a new risk model? Interact Cardiovasc Thorac Surg. 2010;11(5):543-546.

12. Sá MP, Figueira ES, Santos CA, et al. Validation of MagedanzSCORE as a predictor of mediastinitis after coronary artery bypass graft surgery. Rev Bras Cir Cardiovasc. 2011;26(3):386-392.
13. Baskett RJ, MacDougall CE, Ross DB. Is mediastinitis a preventable complication? A 10-year review. Ann Thorac Surg. 1999;67(2):462-465.

14. Bitkover CY, Gårdlund B. Mediastinitis after cardiovascular operations: a case-control study of risk factors. Ann Thorac Surg. 1998;65(1): 36-40.

15. Blanchard A, Hurni M, Ruchat P, Stumpe F, Fischer A, Sadeghi H. Incidence of deep and superficial sternal infection after open heart surgery. A ten years retrospective study from 1981 to 1991. Eur $J$ Cardiothorac Surg. 1995;9(3):153-157.

16. Borger MA, Rao V, Weisel RD, et al. Deep sternal wound infection: risk factors and outcomes. Ann Thorac Surg. 1998;65(4):1050-1056.

17. Braxton JH, Marrin CA, McGrath PD, et al. 10-year follow-up of patients with and without mediastinitis. Semin Thorac Cardiovasc Surg. 2004;16(1):70-76.

18. Breyer RH, Mills SA, Hudspeth AS, Johnston FR, Cordell AR. A prospective study of sternal wound complications. Ann Thorac Surg. 1984;37(5):412-416.

19. Cayci C, Russo M, Cheema FH, et al. Risk analysis of deep sternal wound infections and their impact on long-term survival: a propensity analysis. Ann Plast Surg. 2008;61(3):294-301.

20. Centofanti P, Savia F, La Torre M, et al. A prospective study of prevalence of 60-days postoperative wound infections after cardiac surgery. An updated risk factor analysis. J Cardiovasc Surg (Torino). 2007;48(5):641-646.

21. Culliford AT, Cunningham JN Jr, Zeff RH, Isom OW, Teiko P, Spencer FC. Sternal and costochondral infections following openheart surgery. A review of 2,594 cases. J Thorac Cardiovasc Surg. 1976;72(5):714-726.

22. Danzer D, Christenson JT, Kalangos A, Khatchatourian G, Bednarkiewicz M, Faidutti B. Impact of double internal thoracic artery grafts on long-term outcomes in coronary artery bypass grafting. Tex Heart Inst J. 2001;28(2):89-95.

23. De Feo M, Renzulli A, Ismeno G, et al. Variables predicting adverse outcome in patients with deep sternal wound infection. Ann Thorac Surg. 2001;71(1):324-331.

24. De Moraes AA, Abboud CS, Chammas AZ, et al. Long term mortality of deep sternal wound infection after coronary artery bypass surgery. Rev Bras Cir Cardiovasc. 2012;27(3):377-382.

25. Demmy TL, Park SB, Liebler GA, et al. Recent experience with major sternal wound complications. Ann Thorac Surg. 1990;49(3):458-462.

26. Diez C, Koch D, Kuss O, Silber RE, Friedrich I, Boergermann J. Risk factors for mediastinitis after cardiac surgery - a retrospective analysis of 1700 patients. J Cardiothorac Surg. 2007;2:23.

27. Eklund AM, Lyytikäinen O, Klemets P, et al. Mediastinitis after more than 10,000 cardiac surgical procedures. Ann Thorac Surg. 2006;82(5):1784-1789.

28. Elenbaas TW, Soliman Hamad MA, Schönberger JP, Martens EJ, van Zundert AA, van Straten AH. Preoperative atrial fibrillation and elevated C-reactive protein levels as predictors of mediastinitis after coronary artery bypass grafting. Ann Thorac Surg. 2010;89(3):704-709.

29. Engelman RM, Williams CD, Gouge TH, et al. Mediastinitis following open-heart surgery. Review of two years' experience. Arch Surg. 1973; 107(5):772-778.

30. Fakih MG, Sharma M, Khatib R, et al. Increase in the rate of sternal surgical site infection after coronary artery bypass graft: a marker of higher severity of illness. Infect Control Hosp Epidemiol. 2007; 28(6):655-660.

31. Farsky PS, Graner H, Duccini P, et al. Risk factors for sternal wound infections and application of the STS score in coronary artery bypass graft surgery. Rev Bras Cir Cardiovasc. 2011;26(4):624-629.

32. Filsoufi F, Rahmanian PB, Castillo JG, Mechanick JI, Sharma SK, Adams DH. Diabetes is not a risk factor for hospital mortality following contemporary coronary artery bypass grafting. Interact Cardiovasc Thorac Surg. 2007;6(6):753-758.

33. Fowler VG Jr, O'Brien SM, Muhlbaier LH, Corey GR, Ferguson TB, Peterson ED. Clinical predictors of major infections after cardiac surgery. Circulation. 2005;112(9 Supp1):I358-I365. 
34. Garey KW, Kumar N, Dao T, Tam VH, Gentry LO. Risk factors for postoperative chest wound infections due to gram-negative bacteria in cardiac surgery patients. J Chemother. 2006;18(4):402-408.

35. Gaynes R, Marosok R, Mowry-Hanley J, et al. Mediastinitis following coronary artery bypass surgery: a 3-year review. J Infect Dis. 1991;163(1):117-121.

36. Ghotaslou R, Yagoubi AR, Khalili AA, Mahmodian R. Mediastinitis after cardiac surgery in Madani Heart Center, Tabriz, Iran. Jpn J Infect Dis. 2008;61(4):318-320.

37. Grmoljez PF, Barner HH, Willman VL, Kaiser GC. Major complications of median sternotomy. Am J Surg. 1975;130(6):679-681.

38. Grossi EA, Culliford AT, Krieger KH, et al. A survey of 77 major infectious complications of median sternotomy: a review of 7,949 consecutive operative procedures. Ann Thorac Surg. 1985;40(3):214-223.

39. Grossi EA, Esposito R, Harris LJ, et al. Sternal wound infections and use of internal mammary artery grafts. J Thorac Cardiovasc Surg. 1991;102(3):342-346. discussion 346-347.

40. Gwely NDN, Khalaf SA, Abol Maaty RA. Deep median sternotomy wound infection after open heart surgery. Egypt J Surg. 2001;20(4):742-748.

41. Gårdlund B, Bitkover CY, Vaage J. Postoperative mediastinitis in cardiac surgery - microbiology and pathogenesis. Eur J Cardiothorac Surg. 2002;21(5):825-830.

42. Harrington G, Russo P, Spelman D, et al. Surgical-site infection rates and risk factor analysis in coronary artery bypass graft surgery. Infect Control Hosp Epidemiol. 2004;25(6):472-476.

43. Hassan M, Smith JM, Engel AM. Predictors and outcomes of sternal wound complications in patients after coronary artery bypass graft surgery. Am Surg. 2006;72(6):515-520.

44. Hazelrigg SR, Wellons HA Jr, Schneider JA, Kolm P. Wound complications after median sternotomy. Relationship to internal mammary grafting. J Thorac Cardiovasc Surg. 1989;98(6):1096-1099.

45. Hosseinrezaei $\mathrm{H}$, Rafiei $\mathrm{H}$, Amiri M. Incidence and risk factors of sternal wound infection at site of incision after open-heart surgery. $J$ Wound Care. 2012;21(8):408-411.

46. Immer FF, Durrer M, Mühlemann KS, Erni D, Gahl B, Carrel TP. Deep sternal wound infection after cardiac surgery: modality of treatment and outcome. Ann Thorac Surg. 2005;80(3):957-961.

47. Ivert T, Lindblom D, Sahni J, Eldh J. Management of deep sternal wound infection after cardiac surgery-Hanuman syndrome. Scand J Thorac Cardiovasc Surg. 1991;25(2):111-117.

48. Jakob HG, Borneff-Lipp M, Bach A, et al. The endogenous pathway is a major route for deep sternal wound infection. Eur J Cardiothorac Surg. 2000;17(2):154-160.

49. Jiménez-Martínez M, Argüero-Sánchez R, Pérez-Alvarez JJ, MinaCastañeda P. Anterior mediastinitis as a complication of median sternotomy incisions: diagnostic and surgical considerations. Surgery. 1970;67(6):929-934.

50. Jonkers D, Elenbaas T, Terporten P, Nieman F, Stobberingh E. Prevalence of 90-days postoperative wound infections after cardiac surgery. Eur J Cardiothorac Surg. 2003;23(1):97-102.

51. Jurkiewicz MJ, Bostwick J 3rd, Hester TR, Bishop JB, Craver J. Infected median sternotomy wound. Successful treatment by muscle flaps. Ann Surg. 1980;191(6):738-744.

52. Khoo AK, Tan KC, Ong KK. Deep-seated infective mediastinitis in post-coronary artery bypass grafting patients. Ann Acad Med Singapore. 1994;23(6):832-837.

53. Kim J, Hammar N, Jakobsson K, Luepker RV, McGovern PG, Ivert T. Obesity and the risk of early and late mortality after coronary artery bypass graft surgery. Am Heart J. 2003;146(3):555-560.

54. Kohli M, Yuan L, Escobar M, et al. A risk index for sternal surgical wound infection after cardiovascular surgery. Infect Control Hosp Epidemiol. 2003;24(1):17-25.

55. Kubota H, Miyata H, Motomura N, et al. Deep sternal wound infection after cardiac surgery. J Cardiothorac Surg. 2013;8:132.

56. Lepelletier D, Perron S, Bizouarn P, et al. Surgical-site infection after cardiac surgery: incidence, microbiology, and risk factors. Infect Control Hosp Epidemiol. 2005;26(5):466-472.
57. Loop FD, Lytle BW, Cosgrove DM, et al. Maxwell Chamberlain memorial paper. Sternal wound complications after isolated coronary artery bypass grafting: early and late mortality, morbidity, and cost of care. Ann Thorac Surg. 1990;49(2):179-186. discussion 186-187.

58. Lu JC, Grayson AD, Jha P, Srinivasan AK, Fabri BM. Risk factors for sternal wound infection and mid-term survival following coronary artery bypass surgery. Eur J Cardiothorac Surg. 2003;23(6):943-949.

59. Macmanus Q, Okies JE. Mediastinal wound infection and aortocoronary graft patency. Am J Surg. 1976;132(5):558-561

60. Magedanz EH, Bodanese LC, Guaragna JC, et al. Risk score elaboration for mediastinitis after coronary artery bypass grafting. Rev Bras Cir Cardiovasc. 2010;25(2):154-159.

61. Matros E, Aranki SF, Bayer LR, McGurk S, Neuwalder J, Orgill DP. Reduction in incidence of deep sternal wound infections: random or real? J Thorac Cardiovasc Surg. 2010;139(3):680-685.

62. Orita H, Shimanuki T, Fukasawa M, et al. A clinical study of postoperative infections following open-heart surgery: occurrence and microbiological findings in 782 cases. Surg Today. 1992;22(3): 207-212.

63. Paul M, Raz A, Leibovici L, Madar H, Holinger R, Rubinovitch B. Sternal wound infection after coronary artery bypass graft surgery: validation of existing risk scores. J Thorac Cardiovasc Surg. 2007; 133(2):397-403.

64. Milano CA, Kesler K, Archibald N, Sexton DJ, Jones RH. Mediastinitis after coronary artery bypass graft surgery. Risk factors and long-term survival. Circulation. 1995;92(8):2245-2251.

65. Muñoz P, Menasalvas A, Bernaldo de Quirós JC, Desco M, Vallejo JL, Bouza E. Postsurgical mediastinitis: a case-control study. Clin Infect Dis. 1997;25(5):1060-1064

66. Nagachinta T, Stephens M, Reitz B, Polk BF. Risk factors for surgical-wound infection following cardiac surgery. J Infect Dis. 1987;156(6):967-973.

67. Newman LS, Szczukowski LC, Bain RP, Perlino CA. Suppurative mediastinitis after open heart surgery. A case control study of risk factors. Chest. 1988;94(3):546-553.

68. Noyez L, van Druten JA, Mulder J, Schroën AM, Skotnicki SH, Brouwer RM. Sternal wound complications after primary isolated myocardial revascularization: the importance of the post-operative variables. Eur J Cardiothorac Surg. 2001;19(4):471-476.

69. Ochsner JL, Mills NL, Woolverton WC. Disruption and infection of the median sternotomy incision. J Cardiovasc Surg (Torino). 1972; 13(5):394-399.

70. Olsen MA, Lock-Buckley P, Hopkins D, Polish LB, Sundt TM, Fraser VJ. The risk factors for deep and superficial chest surgical-site infections after coronary artery bypass graft surgery are different. J Thorac Cardiovasc Surg. 2002;124(1):136-145.

71. Ottino G, De Paulis R, Pansini S, et al. Major sternal wound infection after open-heart surgery: a multivariate analysis of risk factors in 2,579 consecutive operative procedures. Ann Thorac Surg. 1987;44(2):173-179.

72. Parisian Mediastinitis Study Group. Risk factors for deep sternal wound infection after sternotomy: a prospective, multicenter study. $J$ Thorac Cardiovasc Surg. 1996;111(6):1200-1207.

73. Parissis H, Al-Alao B, Soo A, Orr D, Young V. Risk analysis and outcome of mediastinal wound and deep mediastinal wound infections with specific emphasis to omental transposition. J Cardiothorac Surg. 2011;6:111.

74. Popovic B, Voillot D, Maureira P, et al. Bilateral internal mammary artery bypass grafting: long-term clinical benefits in a series of 1000 patients. Heart. 2013;99(12):854-859.

75. Prabhakar G, Haan CK, Peterson ED, Coombs LP, Cruzzavala JL, Murray GF. The risks of moderate and extreme obesity for coronary artery bypass grafting outcomes: a study from the Society of Thoracic Surgeons' database. Ann Thorac Surg. 2002;74(4):1125-1130. discussion 1130-1.

76. Rahmanian PB, Adams DH, Castillo JG, Carpentier A, Filsoufi F. Predicting hospital mortality and analysis of long-term survival after major noncardiac complications in cardiac surgery patients. Ann Thorac Surg. 2010;90(4):1221-1229. 
77. Careaga Reyna G, Aguirre Baca GG, Medina Concebida LE, Borrayo Sánchez G, Prado Villegas G, Argüero Sánchez R. Risk factors for mediastinitis and sternal dehiscence after cardiac surgery. Rev Esp Cardiol. 2006;59(2):130-135.

78. Ridderstolpe L, Gill H, Granfeldt H, Ahlfeldt H, Rutberg H. Superficial and deep sternal wound complications: incidence, risk factors and mortality. Eur J Cardiothorac Surg. 2001;20(6):1168-1175.

79. Russo PL, Bull A, Bennett N, et al. Infections after coronary artery bypass graft surgery in Victorian hospitals--VICNISS Hospital Acquired Infection Surveillance. Aust N Z J Public Health. 2005;29(3): 244-248.

80. Sachithanandan A, Nanjaiah P, Nightingale P, et al. Deep sternal wound infection requiring revision surgery: impact on mid-term survival following cardiac surgery. Eur J Cardiothorac Surg. 2008;33(4): 673-678.

81. Sakamoto H, Fukuda I, Oosaka M, Nakata H. Risk factors and treatment of deep sternal wound infection after cardiac operation. Ann Thorac Cardiovasc Surg. 2003;9(4):226-232.

82. Salehi Omran A, Karimi A, Ahmadi SH, et al. Superficial and deep sternal wound infection after more than 9000 coronary artery bypass graft (CABG): incidence, risk factors and mortality. BMC Infect Dis. 2007;7:112.

83. Leung Wai Sang S, Chaturvedi R, Alam A, Samoukovic G, de Varennes B, Lachapelle K. Preoperative hospital length of stay as a modifiable risk factor for mediastinitis after cardiac surgery. $J$ Cardiothorac Surg. 2013;8:45.

84. Serry C, Bleck PC, Javid H, et al. Sternal wound complications. Management and results. J Thorac Cardiovasc Surg. 1980;80(6): 861-867.

85. Sharma M, Berriel-Cass D, Baran J Jr. Sternal surgical-site infection following coronary artery bypass graft: prevalence, microbiology, and complications during a 42-month period. Infect Control Hosp Epidemiol. 2004;25(6):468-471.

86. Steingrimsson S, Gottfredsson M, Kristinsson KG, Gudbjartsson T. Deep sternal wound infections following open heart surgery in Iceland: a population-based study. Scand Cardiovasc J. 2008;42(3):208-213.

87. Strecker T, Rösch J, Horch RE, Weyand M, Kneser U. Sternal wound infections following cardiac surgery: risk factor analysis and interdisciplinary treatment. Heart Surg Forum. 2007;10(5):E366-E371.

88. Ståhle E, Tammelin A, Bergström R, Hambreus A, Nyström SO, Hansson HE. Sternal wound complications--incidence, microbiology and risk factors. Eur J Cardiothorac Surg. 1997;11(6):1146-1153.

89. Sutherland RD, Martinez HE, Guynes WA, Miller L. Postoperative chest wound infections in patients requiring coronary bypass. A controlled study evaluating prophylactic antibiotics. J Thorac Cardiovasc Surg. 1977;73(6):944-947.

90. Szabó Z, Håkanson E, Svedjeholm R. Early postoperative outcome and medium-term survival in 540 diabetic and 2239 nondiabetic patients undergoing coronary artery bypass grafting. Ann Thorac Surg. 2002;74(3):712-719.

91. Toumpoulis IK, Anagnostopoulos CE, Toumpoulis SK, De Rose JJ Jr, Swistel DG. Risk factors for sepsis and endocarditis and long-term survival following coronary artery bypass grafting. World J Surg. 2005;29(5):621-627. discussion 627-628.

92. Tang GH, Maganti M, Weisel RD, Borger MA. Prevention and management of deep sternal wound infection. Semin Thorac Cardiovasc Surg. 2004;16(1):62-69.

93. Thurer RJ, Bognolo D, Vargas A, Isch JH, Kaiser GA. The management of mediastinal infection following cardiac surgery. An experience utilizing continuous irrigation with povidone-iodine. J Thorac Cardiovasc Surg. 1974;68(6):962-968. No abstract available.

94. Tiveron MG, Fiorelli AI, Mota EM, et al. Preoperative risk factors for mediastinitis after cardiac surgery: analysis of 2768 patients. Rev Bras Cir Cardiovasc. 2012;27(2):203-210. English, Portuguese.

95. Toumpoulis IK, Anagnostopoulos CE, Derose JJ Jr, Swistel DG. The impact of deep sternal wound infection on long-term survival after coronary artery bypass grafting. Chest. 2005;127(2):464-471.
96. Trick WE, Scheckler WE, Tokars JI, et al. Modifiable risk factors associated with deep sternal site infection after coronary artery bypass grafting. J Thorac Cardiovasc Surg. 2000;119(1):108-114.

97. Upton A, Roberts SA, Milsom P, Morris AJ. Staphylococcal post-sternotomy mediastinitis: five year audit. ANZ J Surg. 2005; 75(4):198-203.

98. Walkes JC, Earle N, Reardon MJ, et al. Outcomes in single versus bilateral internal thoracic artery grafting in coronary artery bypass surgery. Curr Opin Cardiol. 2002;17(6):598-601.

99. Wang FD, Chang $\mathrm{CH}$. Risk factors of deep sternal wound infections in coronary artery bypass graft surgery. J Cardiovasc Surg (Torino). 2000;41(5):709-713.

100. Wilson SJ, Sexton DJ. Elevated preoperative fasting serum glucose levels increase the risk of postoperative mediastinitis in patients undergoing open heart surgery. Infect Control Hosp Epidemiol. 2003;24(10):776-778

101. Wouters R, Wellens F, Vanermen H, De Geest R, Degrieck I, De Meerleer F. Sternitis and mediastinitis after coronary artery bypass grafting. Analysis of risk factors. Tex Heart Inst J. 1994;21(3):183-188.

102. Zacharias A, Habib RH. Factors predisposing to median sternotomy complications. Deep vs superficial infection. Chest. 1996;110(5): 1173-1178.

103. Elwood M. Critical Appraisal of Epidemiological Studies and Clinical Trials. Oxford: Oxford University Press; 2007.

104. Von Elm E, Altman DG, Egger M, Pocock SJ, Gøtzsche PC, Vandenbroucke JP. The strengthening the reporting of observational studies in epidemiology (STROBE) statement: guidelines for reporting observational studies. Lancet. 2007;370:1453-1457.

105. Sanderson S, Tatt ID, Higgins JPT. Tools for assessing quality and susceptibility to bias in observational studies in epidemiology: a systematic review and annotated bibliography. Int $J$ Epidemiol. 2007;36:666-676.

106. Greenland S, O'Rourke K. On the bias produced by quality scores in meta-analysis, and a hierarchical view of proposed solutions. Biostatistics. 2001;2:463-471.

107. DerSimonian R, Laird N. Meta-analysis in clinical trials. Control Clin Trials. 1986;7:177-188.

108. Freeman MF, Tukey JW. Transformations related to the angular and the square root. Ann Math Stat. 1950;21:607-611.

109. Newcombe RG. Two-sided confidence intervals for the single proportion: comparison of seven methods. Stat Med. 1998;17:857-872.

110. Borenstein M, Hegges LV, Higgins JPT, Rothstein H. Introduction to Meta-Analysis. Third ed. Wiltshire, UK: John Wiley \& Sons; 2011.

111. Begg CB, Mazumdar M. Operating characteristics of a rank correlation test for publication bias. Biometrics. 1994;50:1088-1101.

112. Egger M, Smith GD, Schneider M, Minder C. Bias in meta-analysis detected by a simple, graphical test. Br Med J. 1997;315:629-634.

113. Duval S, Tweedie R. Trim and fill: a simple funnel-plot-based method of testing and adjusting for publication bias in meta-analysis. Biometrics. 2000;56(2):455-463.

114. Terrin N, Schmidt C, Lau J, Olkin I. Adjusting publication bias in the presence of heterogeneity. Stat Med. 2003;22:2113-2126.

115. Schwarzer G. meta: an R package for meta-analysis. R News. 2007; $7(3): 40-45$.

116. StataCorp LP [homepage on the Internet]. STATA Data Analysis and Statistical Software. College Station, TX: StataCorp LP. Available from: www.stata.com. Accessed March 12, 2016.

117. Moher D, Liberati A, Tetzlaff J, Altman DG; PRISMA Group. Preferred reporting items for systematic reviews and meta-analyses: the PRISMA Statement. Ann Intern Med. 2009;151:264-269.

118. Egger M, Smith GD, Altman DG. Systematic Reviews in Health Care: Meta-Analysis in Context. Second ed. London: BMJ Publishing Group; 1995.

119. Shapiro RS, Cowen LE. Thermal control of microbial development and virulence: molecular mechanisms of microbial temperature sensing. MBio. 2012;2;3(5). pii: e00238-12. doi:10.1128/ mBio.00238-12. Print 2012. 
120. Eber MR, Shardell M, Schweizer ML, Laxminarayan R, Perencevich EN Seasonal and temperature-associated increases in gram-negative bacterial bloodstream infections among hospitalized patients. PLoS One. 2011;6(9):e25298.

121. Mermel LA, Machan JT, Parenteau S. Seasonality of MRSA infections. PLoS One. 2011;6(3):e17925.

122. Sahoo KC, Sahoo S, Marrone G, Pathak A, Lundborg CS, Tamhankar AJ. Climatic factors and community-associated methicillin-resistant Staphylococcus aureus skin and soft-tissue infections - a time-series analysis study. Int J Environ Res Public Health. 2014;11(9):8996-9007.

123. Madiraju MV, Brunner DP, Wilkinson BJ. Effects of temperature, $\mathrm{NaCl}$, and methicillin on penicillin-binding proteins, growth, peptidoglycan synthesis, and autolysis in methicillin-resistant Staphylococcus aureus Antimicrob Agents Chemother. 1987;31(11):1727-1733.

124. Ayliffe GA, Noy MF, Babb JR, Davies JG, Jackson J. A comparison of pre-operative bathing with chlorhexidine-detergent and nonmedicated soap in the prevention of wound infection. J Hosp Infect. 1983;4:237-244.

125. Woodhead K, Taylor EW, Bannister G, Chesworth T, Hoffman P, Humphreys H. Behaviours and rituals in the operating theatre. A report from the Hospital Infection Society Working Party on Infection Control in Operating Theatres. J Hosp Infect. 2002;51: 241-255.

126. Tanner J, Norrie P, Melen K. Preoperative hair removal to reduce surgical site infection (review). Cochrane Database Syst Rev. 2011;(11):CD004122.
127. Groom RC, Rassias AJ, Cormack JE, et al. Northern New England Cardiovascular Disease Study Group. Highest core temperature during cardiopulmonary bypass and rate of mediastinitis. Perfusion. 2004;19:119-125.

128. Verkkala K, Makela P, Ojajarvi J, Tiittanen L, Hoborn J. Air contamination in open heart surgery with disposable coveralls, gowns and drapes. Ann Thorac Surg. 1990;50:757-760.

129. Berg GA, Kirk AJ, Bain WH. Punctured surgical gloves and bacterial re-colonisation of hands during open heart surgery: implications for prosthetic valve replacement. Br J Clin Pract. 1987;41:903-906.

130. Driever R, Beie M, Schmitz E, et al. Surgical glove perforation in cardiac sugery. Thorac Cardiovasc Surg. 2001;49:328-330.

131. Christensen JB, Andersen BM, Thomassen SM, Johansen O, Lie M. The effects of 'in-use' surgical handwashing on the pre- and postoperative fingertip flora during cardiothoracic and orthopaedic surgery. J Hosp Infect. 1995;95:325-335.

132. Bratzler DW, Houck PM, Richards C, et al. Use of antimicrobial prophylaxis for major surgery:baseline results from the National Surgical Infection Prevention Project. Arch Surg. 2005;38:1706-1715.

133. Bratzler DW, Houck PM; The Surgical Infection Prevention Guidelines Writers Workgroup, et al. Antimicrobial prophylaxis for surgery: an advisory statement from the National Surgical Infection Prevention Project. Clin Infect Dis. 2004;38:1706-1715.

134. Stenhem M, Ortqvist A, Ringberg H, et al. Epidemiology of methicillin-resistant Staphylococcus aureus (MRSA) in Sweden 2000-2003, increasing incidence and regional differences. BMC Infect Dis. 2006;6:30.
Clinical Epidemiology

\section{Publish your work in this journal}

Clinical Epidemiology is an international, peer-reviewed, open access, online journal focusing on disease and drug epidemiology, identification of risk factors and screening procedures to develop optimal preventative initiatives and programs. Specific topics include: diagnosis, prognosis, treatment, screening, prevention, risk factor modification,

Submit your manuscript here: http://www.dovepress.com/clinical-epidemiology-journa

\section{Dovepress}

systematic reviews, risk \& safety of medical interventions, epidemiology \& biostatistical methods, and evaluation of guidelines, translational medicine, health policies \& economic evaluations. The manuscript management system is completely online and includes a very quick and fair peer-review system, which is all easy to use. 